\title{
First record of Biclonuncaria deutera Razowski \& Becker, 1993 (Lepidoptera: Tortricidae) on Arachis repens Handro (Fabales: Fabaceae)
}

\section{Primeiro registro de Biclonuncaria deutera Razowski \& Becker, 1993 (Lepidoptera: Tortricidae) em Arachis repens Handro (Fabales: Fabaceae)}

Hermann Moller ${ }^{1 *}$ (D) (https://orcid.org/0000-0002-4658-9039)

Ronaldo Pavarini ${ }^{2}$ (D) (https://orcid.org/0000-0002-2639-5632)

\begin{abstract}
Arachis repens Handro (Fabales: Fabaceae) peanut grass shoots were collected at São Paulo State University, Campus of Registro, São Paulo, Brazil, in March 2017 to record a Lepidoptera that was injuring the plant. The species was identified as Biclonuncaria deutera Razowski \& Becker, 1993 (Lepidoptera: Tortricidae).
\end{abstract}

KEYWORDS: ornamental plants; potential pest; Vale do Ribeira.
RESUMO: Folhas de grama-amendoim Arachis repens Handro (Fabales: Fabaceae) foram coletadas no Câmpus da Universidade Estadual Paulista, no município de Registro (SP), no mês de março de 2017, para registrar um Lepidoptera que causava injúrias à planta. A espécie foi identificada como Biclonuncaria deutera Razowski \& Becker, 1993 (Lepidoptera: Tortricidae).

PALAVRAS-CHAVE: plantas ornamentais; praga potencial; Vale do Ribeira. 
Arachis repens Handro (Fabales: Fabaceae) (peanut grass) is a species of the family Fabaceae, native to Brazil. Its origin is northern Minas Gerais state, often used as an ornamental plant and forage to prevent soil erosion in gardens, orchards or green roofs (FÁVERO; VALLS, 2018). It is a perennial plant with a fibrous root system, branches with adventitious roots at nodes, tetrafoliate leaves with elliptical to obovate leaflets reaching 20-35 mm long $\times$ 8-12 mm wide (KRAPOVICKAS; GREGORY, 2007).

There are only a few works regarding pests to Arachis wild species. Reported from Pinto peanut Arachis pintoi (KELEMU et al., 1994), they are: leafcutter ants Atta spp. (Hymenoptera: Formicidae); lepidopteran larvae, such as the bean-leaf webworm moth Omiodes indicata (Lepidoptera: Crambidae), synonym Hedylepta indicata; fall armyworm Spodoptera frugiperda (Lepidoptera: Noctuidae); lesser cornstalk borer Elasmopalpus lignosellus (Lepidoptera: Pyralidae); and, red-necked peanutworm moth Stegasta bosqueella (Lepidoptera: Gelechiidae). FAZOLIN et al. (2015) registered arthropods of economic importance to Pinto peanut, emphasizing mites, thrips, beetles and one bug species, but no lepidopterans.

This work presents the first record of Biclonuncaria deutera (Lepidoptera: Tortricidae) on $A$. repens, as well as the description of injuries caused by it.

In March 2017, shoots of $A$. repens with closed leaflets (Fig. 1) were collected in gardens of the São Paulo State University, Campus of Registro (24030'04.7'S 47051'07.5”W), in which small larvae measuring around $10 \mathrm{~mm}$ (Fig. 2) and pupae around $5 \mathrm{~mm}$ in length (Fig. 1b) were found.

The collected material was carried to Unesp Plant Health Laboratory in Registro, placed in Petri plates with humidified filter paper in the bottom and kept in acclimated chambers $\left(25^{\circ} \mathrm{C}, 14 \mathrm{~h}\right.$ photophase) in order to obtain adults for identification to species level. Adults (Fig. 3) were sacrificed with ethyl acetate, mounted on entomological pins and sent to specialist Ph. D. Vitor Osmar Becker, who identified them as $B$. deutera (Lepidoptera: Tortricidae), described by RAZOWSKI; BECKER (1993) from specimens collected in Nova Lima, Minas Gerais, Brazil, in 1983.

The biology of Biclonuncaria is yet unknown. However, Biclonuncaria dalbergiae RAZOWSKI; BECKER (1993) host plant is Dalbergia frutescens (Fabales: Fabaceae), synonym Dalbergia variabilis, from which it has successfully been reared. Distribution of the genus in the Brazilian territory includes the states of Sáo Paulo, Rio de Janeiro, Minas Gerais, Paraná, Santa Catarina and the Federal District (RAZOWSKI; BECKER, 1993).

RAZOWSKI; BECKER (1993) do not describe immature stages of $B$. deutera. Nevertheless, it seems to be remarkably like those of $B$. dalbergiae, said to have larvae around $10 \mathrm{~mm}$ in length, translucid green body, yellow head and brownish pupae around $5 \mathrm{~mm}$ in length.

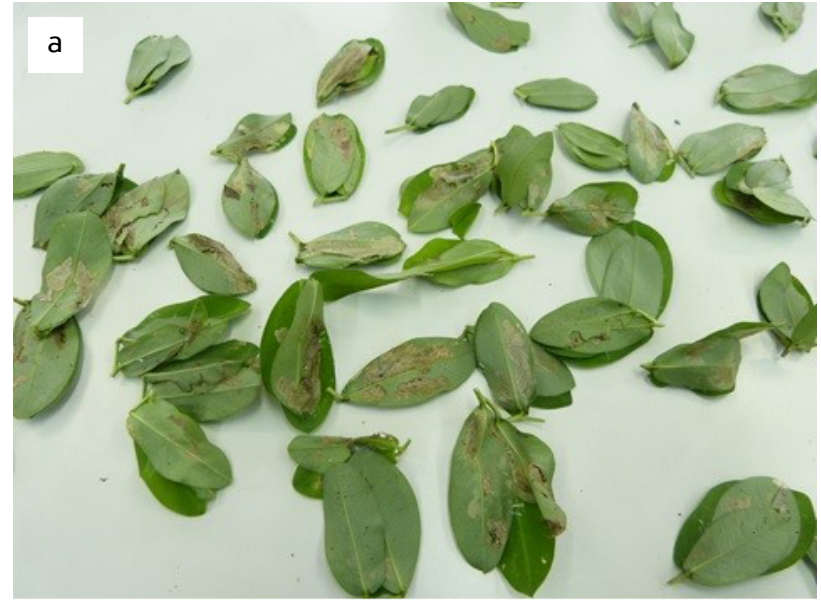

b

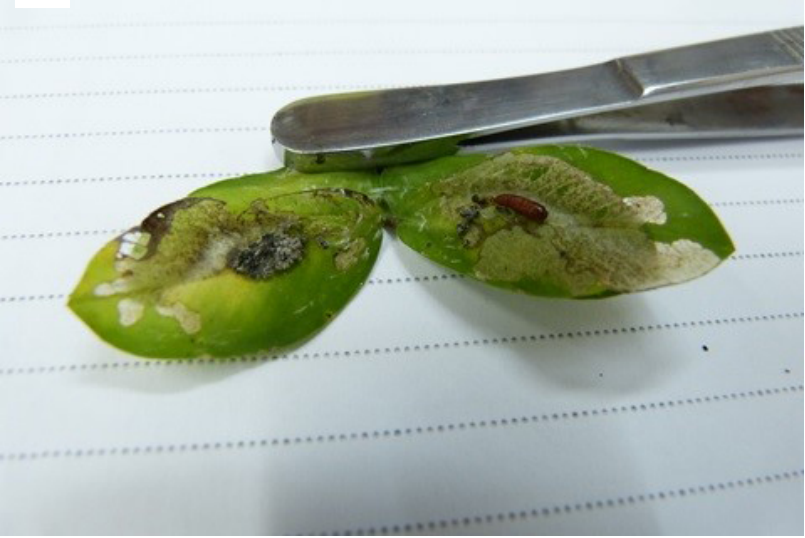

Figure 1. Biclonuncaria deutera injuries on $A$. repens leaves (a); injuries close-up with $B$. deutera pupae (b).

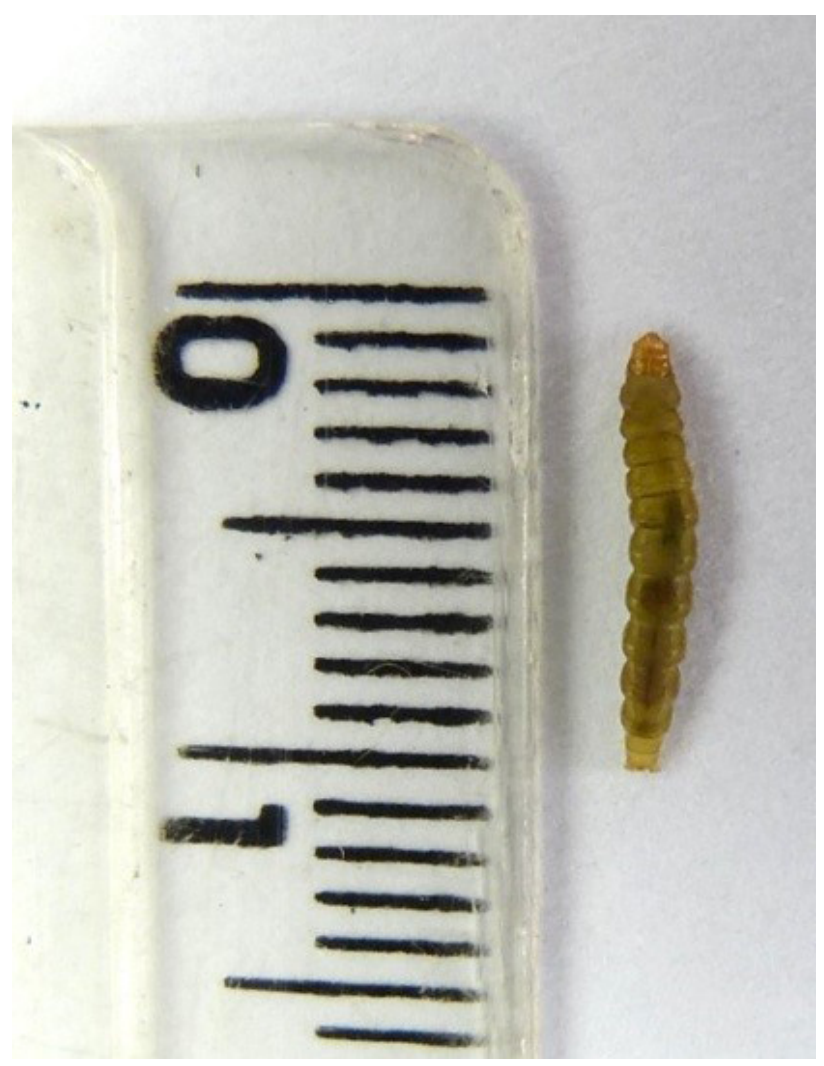

Figure 2. Biclonuncaria deutera final instar larva. 


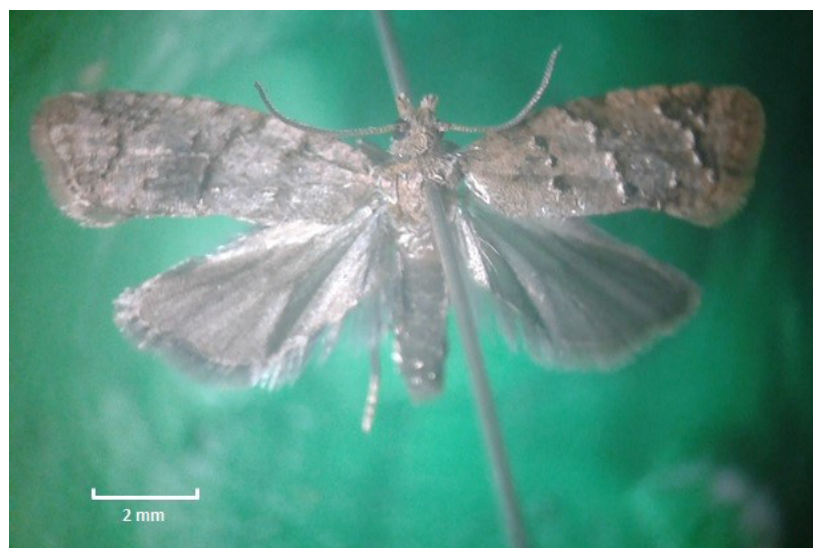

Figure 3. Dorsal view of an adult $B$. deutera.
During its larval stage, $B$. deutera larva spin two to four leaflets together by weaving silk, forming a shelter where it scrapes vegetal tissues for feeding and dwelling inside until the adult emergence (Fig. 1). These injuries resemble those of $O$. indicata on common bean Phaseolus vulgaris L., in which young larvae live between leaves spun together, feeding on their mesophyll (QUINTELA; BARBOSA, 2015).

These injuries damage the leaves, compromising the aesthetics of this ornamental plant, turning $B$. deutera into a potential pest for gardens with $A$. repens.

ACKNOWLEDGEMENTS: The authors thank Ph. D. Vitor O. Becker, Research Associate at University of Brasília - UnB, Department of Zoology, for identifying $B$. deutera.

FUNDING: This work did not receive any specific grant from funding agencies in the public, commercial, or nonprofit sectors.

CONFLICTS OF INTEREST: The authors certify that they have no commercial or associative interest that represents a conflict of interest in connection with the manuscript.

ETHICAL APPROVAL: Not applicable.

AVAILABILITY OF DATA AND MATERIAL: Data sharing not applicable to this article as no datasets were generated or analyzed during the current study.

AUTHORS' CONTRIBUTIONS: Methodology: Moller, H.; Pavarini, R. Supervision: Pavarini, R. Validation: Pavarini, R. Writing - original draft: Moller, H. Writing - review \& editing: Moller, H.; Pavarini, R.

| || | | | | | | | | | | | | | | | | | | | | | | | | | | | | | | | | | | | | | | | | | | | | | | | | | | | | | | | | | | | | | | | | | | | | | | | | | | | | | | | | | | | | | | | | | | | | | | | | | | | | | | | | | | | | | | | | | | | | | | | | | | | | | | | | | | | | | | | | | | | | | | | | | | | | | | | | | | | | | | | | | | | | | | | | | | | | | | | | | | | | | | | | | | | | | | | | | | | | | | | || ||

\section{REFERENCES}

FÁVERO, A.P.; VALLS, J.F.M. Arachis repens: Grama-amendoim. In: CORADIN, L.; CAMILLO, J.; PAREYN, F.G.C. (eds). Espécies Nativas da Flora Brasileira de Valor Econômico Atual ou Potencial: Plantas para o Futuro: Região Nordeste. Brasília: MMA, 2018. p.1085-1088. Available from: https://ainfo. cnptia.embrapa.br/digital/bitstream/item/190036/1/ Livro-Nordeste-2 1-12-2018-split-merge.pdf. Access on: 19 Jan. 2020.

FAZOLIN, M.; VASCONCELOS, G.J.N.; LIMA, E.F.B.; SANTOS, R.S.; AZEVEDO, H.N. Reconhecimento de artrópodes de importância econômica para o amendoim forrageiro (Documentos 137). Rio Branco: Embrapa Acre, 2015. 64p. Available from: https://ainfo. cnptia.embrapa.br/digital/bitstream/item/136499/1/25831. pdf. Access on: 19 Jan. 2020.
KELEMU, S.; LAPOINTE, S.; MORALES, F. Diseases and Pests of Wild Arachis Species. In: KERRIDGE, P.C.; HARDY, B. (eds). Biology and Agronomy of Forage Arachis. Cali: CIAT, 1994. chap.8, p.95-101.

KRAPOVICKAS, A.; GREGORY, W.C. Taxonomy of the Genus Arachis (Leguminosae). Bonplandia, Corrientes, v.16, p.7-205, 2007. Supplementary. https://doi.org/10.30972/bon. 160158

QUINTELA, E.D.; BARBOSA, F.R. Manual de identificação de insetos e outros invertebrados pragas do feijoeiro (Documentos 246). Santo Antônio de Goiás: Embrapa Arroz e Feijão, 2015. 91.

RAZOWSKI, J.; BECKER, V.O. The Neotropical Polyorthini Biclonuncaria, new genus (Lepidoptera: Tortricidae) and its eleven new species. Revista Brasileira de Entomologia, São Paulo, v.37, n.3, p.507-522, 1993. 